\title{
Antecedents for the Success of the Adoption of Organizational ERP Among Higher Education Institutions and Competitive Advantage in Egypt
}

\author{
Mohamed Soliman \\ Operations Department, School of Management \\ Universiti Sains Malaysia, USM, Malaysia, 11800 USM \\ Penang, Malaysia \\ soliman2002s@yahoo.com
}

\author{
Noorliza Karia \\ Operations Department, School of Management \\ Universiti Sains Malaysia, USM, Malaysia, 11800 USM \\ Penang, Malaysia \\ noorliza@usm.my
}

\begin{abstract}
Although the Enterprise Resource Planning (ERP) system has long been acknowledged in higher education institutions (HEIs) to improve their performance and efficiency, there are not many HEIs in Egypt that adopt ERP system and those that do are in an early stage. The research on ERP system in HEI is still limited and in the immature stage, hence little is known about the success factors for the adoption stage of ERP systems. Consequently, this article aims to understand what are the success factors for ERP adoption and further develop a conceptual model that explains the successful implementation of ERP in HEIs and its impact on competitive advantage. Based on previous studies, this paper identifies and conceptualizes success factors for ERP and further develops the proposed model for the adoption of ERP system in HEIs. This article contributes to the development of the theoretical framework of the successful implementation of the ERP system to explain the competitive advantage of HEI by merging information system (IS) success and diffusion of innovation (DOI) theories with the success factors for the adoption stage of ERP systems. The current study will provide recommendations and guidelines for both the potential adopters and the vendors on the successful ERP system adoption.
\end{abstract}

Keywords-Adoption; Enterprise Resource Planning; IS success model; DOI; ERP; HEIs; Critical Success Factors; Competitive advantage; Higher education; Egypt

\section{INTRODUCTION}

The adoption of the ERP system in universities was intended to create progressive levels of efficiency and performance so that colleges, departments, and schools can improve on their education and research at a low or practical cost [3]. The ERP system is defined as the innovative technology within the HEIs due to its benefits [4]. Due to substantial benefits of the ERP system, several universities have allocated an investment of more than five billion dollars for the system [5]. However, some ERP projects might have some flaws due to the complexity of the implementation process, the misfit between ERP system and organizational business processes, the lack of skilled human capital, cross- functional coordination issues, inappropriate planning and project management, and incompetent consultants [6]. All the listed reasons for the flaws confirmed that it is essential to have a deep understanding on the innovation process in the effort to achieve the success in ERP projects [7]. Furthermore, most of the ERP literature reviews concentrated on the implementation phase such as the implementation of CSFs to ERP in particular $[8,9]$. This trend has resulted in a relatively limited understanding of the other stages of ERP innovation process such as adoption, use, and retirement [10]. Hence, it is important to avoid this "one size fit all" approach and any conceptual that overlap between the implementation and other stages of the ERP innovation process [11]. The adoption stage is the decision-making stage in the innovation process [1]. Therefore, a great understanding of CSFs relating to the adoption stage enable the organizations to save on the costs and time, as well as diminishing the risks of any failures by creating an ideal environment and adequately preparing themselves [12]. Due to the limited research on CSFs relating to ERP adoption, the first objective of this research is to close the gap by determining the factors that are critical to the success of adoption phase.

There are limited studies conducted on ERP settings in Egyptian universities. In a recent research, the result indicates that the ERP implementation success rate is relatively poor in the Egypt organizations compared to the western organizations [13]. The same author also reported that nearly 50 per cent of the ERP implementation failed in Egyptian enterprises. Consequently, the second objective of this research is to investigate the factors that can influence the adoption success of ERP in Egyptian organizations, especially in HEIs. As a result, this research aims to construct a research model by extending the most popular IS success theory [14] with DOI theory [1] and some independent CSFs. Within the Egyptian context, there are not many studies done that examine the determining factors of ERP adoption among HEIs. The literature revealed that the application of ERP system in Egypt focuses on two phases: pre-implementation and 
implementation [15, 16]. In [17], authors clarified that the higher education sector in Egypt is enormous and includes public, private, and foreign universities, besides institutions of technical and skilled training. There are a lot of problems that occurred in the higher education institutions, and the ERP system can emphatically contribute to the changes, as well as diminishing the impacts of these issues. However, the total utilization of ERP has not been embraced by the largest sector of HEIs in Egypt. In conclusion, this research is among the few research that focus on the determinants of ERP adoption in the higher education sector in Egypt.

This research will answer three research questions: 1) How can IS success model, DOI theory, and CSFs be utilised for the success of the adoption of ERP among HEIs in Egypt? 2) To what extent can IS success model, DOI theory, and CSFs influence the success of the adoption of ERP among HEIs in Egypt? 3) What is the factor that can influence the success of the adoption of ERP among HEIs in Egypt?

\section{THEORETICAL BACKGROUND}

\section{A. Previous studies on IS Success Model}

In [14], authors posited that system quality and information quality have the ability to jointly and separately affect the use and users' satisfaction, which can have resulted in individual impact and subsequent organizational impacts. Further research on this model had led to the addition of dimensions such as service quality, intention to use, and net benefits (replacing organization impact construct) [18]. Many ERP studies incorporated this IS success model to measure the success, performance, and net benefits of ERP adoption and implementation [19-26].

\section{B. Previous studies on Diffusion of Innovation (DOI) theory}

In [1], the innovation process was defined in terms of individual and organizational lenses by focusing on the attributes that can affect the process. It was explained that the innovation process within the organization comprised of five stages: two-stage of initiation sub-process, namely agendasetting and matching; and three-stage implementation subprocess, namely redefining/restructuring, clarifying and routinizing. These innovation models have been tested in crossdisciplinary contexts. Many scholars have also presented updates, extensions, and revisions relating this model. DOI model was termed as being too formulaic and lacking in realism [27]. Given the scope of this research, the authors employed the DOI theory as it has the ability to achieve the objectives of the research.

\section{Critical Success Factors CSFs}

In [28], authors developed the concept of CSFs as "characteristics, conditions, or variables that when properly sustained, maintained, or managed, can have a significant impact on the success of a firm that is competing in a particular industry". The current research adopts this view and definition as its fundamental concept. The determination of CSFs is vital to organizations as it is used to constantly and sufficiently focus on activities in the already identified key areas or identify key areas in achieving improvements of the performance [11].

The CSFs are assumed to provide a positive and beneficial effect on the outcome; thus, knowing a greater number of CSFs pertaining to a specific innovation process has been considered as critical to the success of the process [29]. Despite the fact that CSFs are linked to the performance impacts of the firms, there is still a very significant gap in the literature in terms of understanding the true role of CSFs. Generally, the previous studies on CSFs seemed to conceptualize them as an independent object that is relevant to a certain process. The investigations were done without examining the importance of CSF on performance improvements. This situation requires further examination of the role of CSFs in their interactive effect on performance improvements of the firms [11].

\section{RESEARCH MODEL AND HYPOTHESES}

There is the lack of research effort in linking the IS success model and DOI theory with the independent CSFs. Several studies were done to prove the significant impact of the broader concept of technology adoption. Therefore, one of the contributions of this research is to cover the gap in the literature by linking these theories and examining the impact of the factors on the success of ERP adoption among HEIs in Egypt. This research also investigates the attributes that are critical to the adoption of ERP and their effect on competitive advantage. Consistent with the broad category of attributes that was identified in the IS success theory, this research uses innovation related, organizational and IS Success related factors to create a hypothetical model as shown in Figure 1.

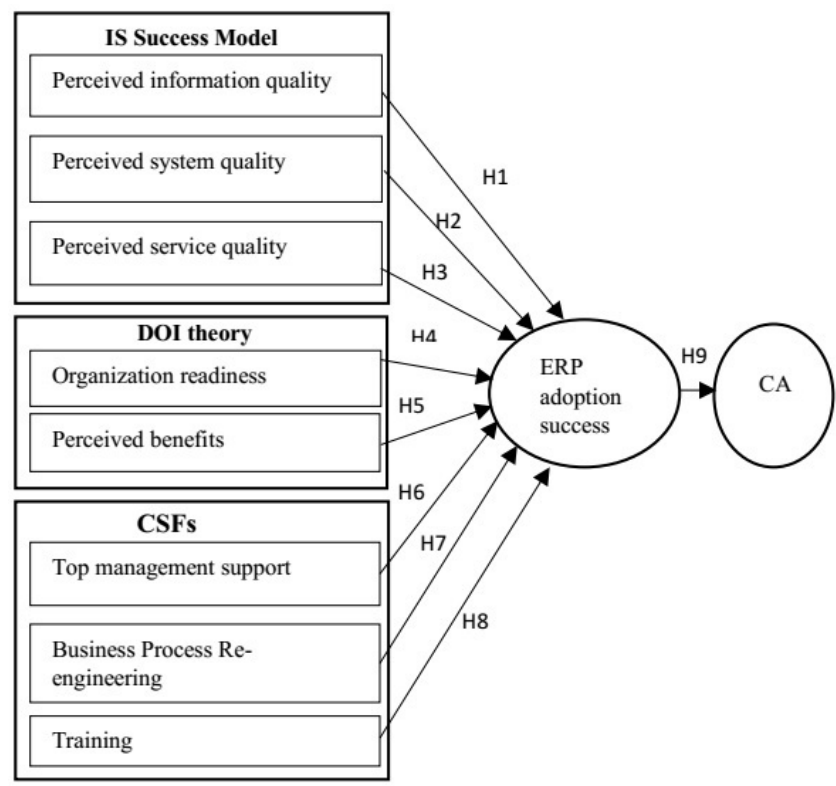

Fig. 1. Proposed research framework

\section{A. Perceived Information Quality}

The information quality within any information system is referred to the measures of its output, and it has been measured 
in terms of accuracy, output precision, output reliability, information timeliness, information relevance on decisions, completeness, format, and understanding ability and many more $[18,30]$. Information quality has been found to be positively linked to user satisfaction [30]. This shows that ERP information quality is critical to the success of adoption of the system. Additionally, ERP system is recognized to provide reliable, accurate, and timely information. Hence, it is confirmed that the quality of ERP's perceived information is a positive contributing factor towards the decision of adoption.

- H1: The ERP's ability to provide quality information can positively influence the success of ERP adoption among HEIs.

\section{B. Perceived System Quality}

According to [18], system quality dimension has been found to be one of the most important enablers of IS success. System quality has been measured in many ways, including convenience of access, integration capabilities, reliability, ease of learning, resource utilization, investment utilization, flexibility of the system, response time, and usefulness of specific function. [18, 30]. It is also perceived as a key factor for ERP implementation besides being positively associated with user satisfaction [30]. The ERP system is supposed to provide integration, flexibility, and optimum resource utilization, which can lead to high system quality. Thus, the ERP's capabilities in system quality is an important factor that can affect the success of adoption among HEIs.

- H2: The ERP's ability to provide system quality can positively influence the success of ERP adoption among HEIs.

\section{Perceived Service Quality}

A revised model was provided in [2] by adding a service quality dimension to the model due to the fact that this dimension can capture the quality of services that a particular information system provides to an organization. Moreover, it also integrates the individual impact and organizational impact dimensions into a new dimension called net benefits, besides adding the intention to use dimension. As a result, information systems can affect the individual user or the organization as well the work group, inter organizational units, intra organizational units, consumers, and society.

- H3: The ERP's ability to provide quality service can positively influence the success of ERP adoption among HEIs.

\section{Organisational Readiness}

In [31], authors defined organizational readiness as "the ability of a firm to successfully adopt, use, and benefit from information technologies". Earlier studies have used several measures to investigate readiness as the following: awareness of benefits and risks of innovation; availability of human resources skills and capabilities; availability of technological, business and financial resources, commitment and support by top management; fit between innovation and organizational structure; as well as goals and values of organization [31, 32].
Based on the findings of the structural contingency theory of fit, [33] the assessment of 'readiness' for an organization to adopt a certain technology is an important criterion for the success of the implementation and performance impact. Organizational readiness can positively impact the adoption of technological innovations [32]. Hence, the internal organizational awareness is critical to the success of ERP adoption.

- H4: Organisational readiness can positively influence the success of ERP adoption among HEIs.

\section{E. Perceived Benefits}

The perceived ERP benefits is referred to what extent can the new ERP system provides more benefits than the conventional ones [34]. The importance of expected benefits in pre-adoption and post-adoption performance has been identified in technology research [35, 36]. Moreover, many empirical studies have validated that positive perceptions of benefits or relative advantages of new information and communication technologies can drive an incentive for their acceptance and utilization [37, 38]. Perceived benefits are one of key determinants of e-business technology adoption as it covers factors such as enhancing competitiveness of the firm [39], increasing efficiency and effectiveness of information flow [40], reducing operating cost of technology [41], and improving manufacturing flexibility, system integration and process innovation [42]. In addition, [43] indicated that firms that have greater perceived relative advantage of enterprise systems are predicted to become adopters of these systems. Kim and Garrison [44] revealed that perceived benefits of RFID have a significant role in its adoption and implementation in South Korea. [45] and [46] they also validated that the expected benefit of e-business is a vital factor that shapes the e-business diffusion. Previous argument mentioned that the potential benefits of new enterprise technology can motivate firms to increase their readiness level in implementing the technology.

- H5: The expected ERP benefits can positively influence the success of ERP adoption among HEIs.

\section{F. Top Management Support}

In [47], it was affirmed that the initial direction of a business in an ERP initiative is to gain full commitment from senior executives. Researchers often hypothesize that the attitude of the top management to change has a significant influence on the adoption outcomes [48]. The active involvement, vision, and direction of high-level executives can provide the drive needed to sustain the implementation of ERP systems [49]. Top management must direct strong signals to different parts of the organization on the significance of a project [50]. The support from the top management can lead to the realization of organizational benefits and provide credibility to the functional managers who are responsible for the implementation and use of ERP [51].

- H6: The degree of top management support on the adoption of ERP system has a positive relationship with the success of ERP adoption among HEIs. 


\section{G. Business Process Re-engineering}

The ERP system is designed for best practices in specific industries [49]. Nevertheless, this system may not be essentially fit for the operating practices in the institution. Accordingly, the ERP software package can either be customized to better fit a company' $\mathrm{s}$ needs or the company must change its business processes to adapt to the ERP software package requirements [52]. Most of ERP experts confirmed that the customization of the ERP software can lead to higher implementation costs and time consumption. Therefore, companies should keep the ERP package "as it is" as much as possible and re-engineer their business processes to conform to the package [53, 54]. An organization that reengineers processes to the best practices of ERP will experience benefit as a result of the implementation. Besides that, the organization will most likely to experience a smoother implementation of the system, which will maximize the stakeholder's satisfaction.

- H7: The degree of re-engineering to the best practices of ERP system has a positive relationship with the success of ERP adoption among HEIs.

\section{H. Training}

It is important to give training to the users due to the inherent complexity of ERP system [53]. One of the greatest advantages of ERP is the integration of data, which can also be a double-edged sword when the system experienced any errors. An error in the upstream can instantly affect the flow down the line; consequently, the employees should be aware of these type of problems for any mistakes that can occur [55]. It is clearer that the training to the users of ERP systems results in greater achievement in terms of organizational performance measures. Moreover, the allocation of the essential resources for training can enhance the users' satisfaction.

- H8: The employees' level of training on the ERP system has a positive relationship with the success of ERP adoption among HEIs.

I. The Success of ERP adoption and Competitive Advantage (CA)

In [56], authors reported that "a company achieves competitive advantage by implementing a value creating a strategy that is not being implemented by competing firms". Therefore, the adoption of strategic information system such as ERP has been linked to achieving capabilities as the following: 1) agility in offering innovative products and services; 2) effective leveraging of resources; 3) raising entry barriers for new competitors; 4) achieving increased bargaining power with suppliers and customers; and 5) changing the dynamics of competition [57]. Furthermore, HEIs can gain a competitive advantage through the adoption of ERP system due to the higher quality of educational services for a lower cost; ERP system can also enable them to effectively use their resources [58]. On the other hand, ERP system might not provide a competitive advantage when directly adopted, although the information can be provided through faster processing of data and given the access at the right time [59]. There is a gap in the knowledge regarding how the adoption and implementation of ERP system can contribute to competitive advantage, especially in the higher education sector, particularly in Egypt.
- H9: The success of ERP adoption is positively linked to the competitive advantage for the HEIs.

\section{DISCUSSION AND CONCLUSION}

To conclude, this research is designed to understand the success of the determinants of ERP adoption among HEIs in Egypt. Also, it can contribute to the literature review of IT adoption, ERP and higher education by 1) improving our understanding on the adoption stage of ERP within the higher education context unlike previous studies that examined ERP adoption among other contexts, 2) identifying factors of the successful ERP adoption among HEIs to gain a competitive advantage, and 3) extending the use of IS success model, DOI theory, and some CSFs within ERP adoption among HEIs. This contribution might eliminate or reduce the risk of failure, as well as improving the chances of success of their ERP projects. Moreover, this research also provides a better understanding of whether the CSF's role is limited to influencing the outcome of the relevant stage in an innovation process or also has the ability to influence the competitive advantage. Practically, this research can help ERP vendors to understand the needs of potential ERP adopters, so that they can formulate their marketing and product development activities to increase their market share as well as adopting a new theoretical framework of 'successful adoption' of ERP. However, this research has several limitations such as limited number of antecedents pertaining to ERP adoption stage. Hence, there is the need for future research in investigating more factors in order to get an agreeable set of CSFs. The outcomes of this research are also limited due to the geographical focus on Egyptian HEIs. Overall, this research is important in helping HEIs to achieve competitive advantages through the adoption of ERP.

\section{ACKNOWLEDGEMENT}

This research is supported by USM fellowship from Institute of Postgraduate Studies (IPS) in Universiti Sains Malaysia (USM). The authors would like to thank the School of Management for providing these facilities for this research.

\section{REFERENCES}

[1] E. M. Rogers, Diffusion of Innovations, 5th Edition: Free Press, 2003.

[2] W. H. Delone, E. R. McLean, "The DeLone and McLean model of information systems success: a ten-year update", Journal of Management Information Systems, Vol. 19, pp. 9-30, 2003

[3] E. E. Watson, H. Schneider, "Using ERP systems in education", Communications of the AIS, Vol. 1, p. 3, 1999

[4] M. Soliman, N. Karia, "Enterprise Resource Planning (ERP) system as an Innovative Technology in Higher Education Context in Egypt", International Journal of Computing Academic Research, Vol. 5, pp. 265269,2015

[5] A. Abugabah, L. Sanzogni, "Enterprise resource planning (ERP) system in higher education: A literature review and implications", International Journal of Human and Social Sciences, Vol. 5, pp. 395-399, 2010

[6] Y. Kim, Z. Lee, S. Gosain, "Impediments to successful ERP implementation process", Business Process Management Journal, Vol. 11, pp. 158-170, 2005

[7] S. Laukkanen, S. Sarpola, P. Hallikainen, "Enterprise size matters: objectives and constraints of ERP adoption", Journal of Enterprise Information Management, Vol. 20, pp. 319-334, 2007. 
[8] Y. B. Moon, "Enterprise Resource Planning (ERP): a review of the literature", International Journal of Management and Enterprise Development, Vol. 4, pp. 235-264, 2007

[9] J. Esteves and V. W. Bohórquez, "An updated ERP systems annotated bibliography: 2001-2005", Instituto de Empresa Business School Working Paper No. WP, pp. 07-04, 2007

[10] E. M. Kamhawi, "Enterprise resource-planning systems adoption in Bahrain: motives, benefits, and barriers", Journal of Enterprise Information Management, Vol. 21, pp. 310-334, 2008

[11] J. Ram and M. Pattinson, "Exploring antecedents of organisational adoption of ERP and their effect on performance of firms", ECIS, pp. 1174-1186, 2009

[12] J. Verville, C. Bernadas, and A. Halingten, "So you're thinking of buying an ERP? Ten critical factors for successful acquisitions", Journal of Enterprise Information Management, Vol. 18, pp. 665-677, 2005

[13] H. Abdellatif, "ERP in higher education: a deeper look on developing countries", The International Conference on Education Technologies and Computers, pp. 73-78, 2014

[14] W. H. DeLone, E. R. McLean, "Information systems success: The quest for the dependent variable", Information Systems Research, Vol. 3, pp. $60-95,1992$

[15] H. El Sayed, "Management Control and ERP Systems: A Case Study from Egypt, The International Conference on Industrial Logistics, Croatia, June 14-16, 2012

[16] M. El Sayed, N. J. Hubbard, N. S. Tipi, "Evaluating enterprise resource planning (ERP) post implementation problems in Egypt: Findings from case studies of governmental, multinational and private Egyptian organisations", LRN Annual Conference and PhD Workshop, Birmingham, UK, September 4-6, 2013

[17] S. El-Seoud, I. Taj-Eddin, N. Seddiek, P. Ghenghesh, M. El-Khouly, "The Impact of E-Learning on Egyptian Higher Education and its Effect on Learner's Motivation: A Case Study", Computer Science and Information Technology, Vol. 2, pp. 179-187, 2014

[18] W. H. Delone, E. R. Mclean, "Measuring e-commerce success: Applying the DeLone \& McLean information systems success model", International Journal of Electronic Commerce, Vol. 9, pp. 31-47, 2004

[19] E. W. Bernroider, "IT governance for enterprise resource planning supported by the DeLone-McLean model of information systems success", Information \& Management, Vol. 45, pp. 257-269, 2008

[20] H. Lin, "An investigation into the effects of IS quality and top management support on ERP system usage", Total Quality Management, Vol. 21, pp. 335-349, 2010

[21] P. Ifinedo, "Examining the influences of external expertise and in-house computer/IT knowledge on ERP system success", Journal of Systems and Software, Vol. 84, pp. 2065-2078, 2011

[22] W. Tsai, M. J. Shaw, Y. Fan, J. Liu, K. Lee, H. Chen, "An empirical investigation of the impacts of internal/external facilitators on the project success of ERP: A structural equation model", Decision Support Systems, Vol. 50, pp. 480-490, 2011

[23] W. Tsai, K. Lee, J. Liu, S. Lin, Y. Chou, "The influence of enterprise resource planning (ERP) systems' performance on earnings management", Enterprise Information Systems, Vol. 6, pp. 491-517, 2012

[24] J.-S. Chou, J.-H. Hong, "Assessing the impact of quality determinants and user characteristics on successful enterprise resource planning project implementation", Journal of Manufacturing Systems, Vol. 32, pp. 792-800, 2013

[25] S. Nizamani, K. Khoumbati, I. A. Ismaili, S. Nizamani, "A Conceptual Framework for ERP Evaluation in Universities of Pakistan", Sindh Univ. Res. Jour. (Sci. Ser.), Vol. 45, No. 3, pp. 596-607, 2013

[26] M. A. M. B. Lotfy, Sustainability of Enterprise Resource Planning (ERP) Benefits Postimplementation: An Individual User Perspective, PhD Thesis, Walden University, 2015

[27] J. Bayer, N. Melone, "A critique of diffusion theory as a managerial framework for understanding adoption of software engineering innovations", Twenty-First Annual Hawaii International Conference on System Sciences, Vol. II. Software Track, pp. 311-316, 1988
[28] J. K. Leidecker, A. V. Bruno, "Identifying and using critical success factors", Long Range Planning, Vol. 17, pp. 23-32, 1984

[29] J. Karim, T. M. Somers, A. Bhattacherjee, "The impact of ERP implementation on business process outcomes: A factor-based study", Journal of Management Information Systems, Vol. 24, pp. 101-134, 2007

[30] R. R. Nelson, P. A. Todd, B. H. Wixom, "Antecedents of information and system quality: an empirical examination within the context of data warehousing", Journal of Management Information Systems, Vol. 21, pp. 199-235, 2005

[31] M. Fathian, P. Akhavan, M. Hoorali, "E-readiness assessment of nonprofit ICT SMEs in a developing country: The case of Iran", Technovation, Vol. 28, pp. 578-590, 2008

[32] A. Molla, P. S. Licker, "Perceived e-readiness factors in e-commerce adoption: An empirical investigation in a developing country", International Journal of Electronic Commerce, Vol. 10, pp. 83-110, 2005

[33] D. Khazanchi, "Information technology (IT) appropriateness: The contingency theory of "FIT" and IT Implementation in small and medium enterprises", Journal of Computer Information Systems, Vol. 45, pp. 88-95, 2005

[34] M. G. Aboelmaged, "Predicting e-readiness at firm-level: An analysis of technological, organizational and environmental (TOE) effects on emaintenance readiness in manufacturing firms", International Journal of Information Management, Vol. 34, pp. 639-651, 2014

[35] R. B. Cooper and R. W. Zmud, "Information technology implementation research: a technological diffusion approach", Management Science, Vol. 36, pp. 123-139, 1990

[36] E. M. Rogers, "Diffusion of Innovations: modifications of a model for telecommunications", Die Diffusion von Innovationen in der Telekommunikation, Springer, pp. 25-38, 1995

[37] P. Y. Chau, K. Y. Tam, "Factors affecting the adoption of open systems: an exploratory study", MIS Quarterly, Vol. 21, No. 1, pp. 1-24, 1997

[38] G. Kannabiran, P. Dharmalingam, "Enablers and inhibitors of advanced information technologies adoption by SMEs: An empirical study of auto ancillaries in India", Journal of Enterprise Information Management, Vol. 25, pp. 186-209, 2012

[39] A. Bayo-Moriones, F. Lera-López, "A firm-level analysis of determinants of ICT adoption in Spain", Technovation, Vol. 27, pp. 352366,2007

[40] H. Ongori, S. O. Migiro, "Information and communication technologies adoption in SMEs: literature review", Journal of Chinese Entrepreneurship, Vol. 2, pp. 93-104, 2010

[41] N. Al-Qirim, "The adoption of eCommerce communications and applications technologies in small businesses in New Zealand", Electronic Commerce Research and Applications, Vol. 6, pp. 462-473, 2008

[42] L. Raymond, F. Bergeron, "Enabling the business strategy of SMEs through e-business capabilities: A strategic alignment perspective", Industrial Management \& Data Systems, Vol. 108, pp. 577-595, 2008

[43] B. Ramdani, P. Kawalek, O. Lorenzo, "Predicting SMEs' adoption of enterprise systems", Journal of Enterprise Information Management, Vol. 22, pp. 10-24, 2009

[44] S. Kim, G. Garrison, "Understanding users' behaviors regarding supply chain technology: Determinants impacting the adoption and implementation of RFID technology in South Korea", International Journal of Information Management, Vol. 30, pp. 388-398, 2010

[45] H.-F. Lin, S.-M. Lin, "Determinants of e-business diffusion: A test of the technology diffusion perspective", Technovation, Vol. 28, pp. 135-145, 2008

[46] K. Zhu, S. Dong, S. X. Xu, K. L. Kraemer, "Innovation diffusion in global contexts: determinants of post-adoption digital transformation of European companies", European Journal Of Information Systems, Vol. 15, pp. 601-616, 2006

[47] S. P. Laughlin, "An ERP game plan", Journal of Business Strategy, Vol. 20, pp. 32-37, 1999 
[48] F. Wu, V. Mahajan, S. Balasubramanian, "An Analysis of E-Business Adoption and Its Impact on Business Performance", Journal of the Academy of Marketing Science, Vol. 31, No. 4, pp. 425-447, 2003

[49] D. E. O'Leary, Enterprise resource planning systems: systems, life cycle, electronic commerce, and risk: Cambridge University Press, 2000

[50] M. K. McGowan, G. R. Madey, "The influence of organization structure and organizational learning factors on the extent of EDI implementation in US firms", Information Resources Management Journal, Vol. 11, pp. 17-27, 1998

[51] M. Bradford, J. Florin, "Examining the role of innovation diffusion factors on the implementation success of enterprise resource planning systems", International Journal of Accounting Information Systems, Vol. 4, pp. 205-225, 2003

[52] R. L. Jenson, I. R. Johnson, "The enterprise resource planning system as a strategic solution", Information Strategy: The Executive's Journal, Vol. 15, pp. 28-33, 1999

[53] P. Bingi, M. K. Sharma, J. K. Godla, "Critical issues affecting an ERP implementation", IS Management, Vol. 16, pp. 7-14, 1999

[54] T. H. Davenport, "Putting the enterprise into the enterprise system", Harvard Business Review, Vol. 76, pp. 121-131, 1998
[55] C. Stedman, "ERP can magnify errors", Computerworld, Vol. 32, pp. 13, 1998

[56] B. Dehning, T. Stratopoulos, "DuPont analysis of an IT-enabled competitive advantage", International Journal of Accounting Information Systems, Vol. 3, pp. 165-176, 2002

[57] G. D. Bhatt, V. Grover, "Types of information technology capabilities and their role in competitive advantage: An empirical study", Journal of Management Information Systems, Vol. 22, pp. 253-277, 2005

[58] M. Soliman, N. Karia, "Enterprise Resource Planning Systems in Higher Education Context: Functionalities and Characteristics", International Journal of Innovative Research in Science, Engineering and Technology, Vol. 4, pp. 10408-10413, 2015

[59] B. Johansson, M. Newman, "Competitive advantage in the ERP system's value-chain and its influence on future development", Enterprise Information Systems, Vol. 4, pp. 79-93, 2010 